\begin{tabular}{cc|c}
\hline Tarım Bilimleri Dergisi & Journal of Agricultural Sciences \\
& $\begin{array}{c}\text { Tergi web sayfası: } \\
\text { www.agri.ankara.edu.tr/dergi }\end{array}$ & Journal homepage: \\
& www.agri.ankara.edu.tr/journal
\end{tabular}

\title{
Comparison of the Vacuum Dynamics of Conventional and Quarter Individual Milking Systems
}

\author{
Hülya ÖZ $^{\mathrm{a}}$, Sandra ROSE-MEIERHÖFER ${ }^{\mathrm{b}}$, Ulrich STRÖBEL ${ }^{\mathrm{b}}$, Christian AMMON $^{\mathrm{b}}$ \\ ${ }^{a}$ Ege University, Ege Vocational Training School, Dept. of Agr. Machinery, 35100 Bornova-Izmir, TURKEY \\ ${ }^{b}$ Leibniz Institute for Agricultural Eng. e. V., Dept. of Eng. for Livestock Management, Max-Eyth-Allee 100, 14469 Potsdam, GERMANY
}

\section{ARTICLE INFO}

Research Article - Agricultural Technologies

Corresponding author: Hülya ÖZ, e-mail: hulya.oz@ege.edu.tr, Tel: +90(232) 3111466

Received: 10 February 2010, Received in revised form: 11 September 2010, Accepted: 27 October 2010

\begin{abstract}
The effect of machine milking on udder health has been recognized for the past 100 years. Among different milking systems, a new quarter individual milking system called the Multilactor ${ }^{\circledR}$ (MULTI) has been developed to eliminate some detrimental effects of conventional milking systems $(\mathrm{CON})$ and conventional systems with periodic air ingress (BIO) on udder health. The objective of this study was to determine the effects of milk flow on average liner vacuum during the $b$ and $d$ phases of pulsation in all systems by using a wet-test method defined in ISO 6690 (2007). Measurements were conducted in three different milking parlours where CON, BIO and MULTI were installed separately. It was found that, at an average flow rate of $4.8 \mathrm{lmin}^{-1}$, the average vacuum in the liner during the bphase was $35.0 \mathrm{kPa}$ in $\mathrm{CON}, 32.6 \mathrm{kPa}$ in $\mathrm{BIO}$ and $31.1 \mathrm{kPa}$ in the MULTI system, compliant with the desired average vacuum in the liner of 32-42 $\mathrm{kPa}$ mentioned in ISO 5707 (2007). The average liner vacuum values during the d-phase differs from one system to another and these values were calculated to be $34.2 \mathrm{kPa}, 12.3 \mathrm{kPa}$ and 14.8 $\mathrm{kPa}$ for CON, MULTI and BIO, respectively. The reason why CON differs as compared to MULTI and BIO can be attributed to the fact that both, MULTI and BIO use the BioMilker system that allows periodic air ingress under the teat.
\end{abstract}

Keywords: Liner vacuum; Pulsation; b and d-phase; Vacuum reduction

\section{Geleneksel ve Pençesiz Sağım Sistemlerinin Vakum Dinamiklerinin Karşılaştırılması}

\section{ESER BILGISİ}

Araştırma Makalesi - Tarım Teknolojileri

Sorumlu Yazar: Hülya ÖZ, e-posta: hulya.oz @ege.edu.tr, Tel: +90(232) 3111466

Geliş tarihi: 10 Şubat 2010, Düzeltmelerin gelişi: 11 Eylül 2010, Kabul: 27 Ekim 2010

\section{ÖZET}

Geçen 100 yıl boyunca sağım makinasının meme sağlığı üzerine etkileri farkedilmiştir. Farklı sağım sistemleri arasında, geleneksel sağım sistemlerinin $(\mathrm{CON})$ ve periyodik hava girişi olan geleneksel sağım sistemlerinin (BIO), meme sağlığı üzerindeki zararlı etkilerini ortadan kaldırmak amacıyla Multilactor (MULTI) adı verilen yeni bir pençesiz sağım sistemi geliştirilmiştir. Yapılan bu çalışmanın amacı, ISO 6690 (2007)'da tanımlanmış yaş deneme yöntemini kullanarak, üç sağım sisteminde nabız hareketinin b ve d fazlarında ortalama meme lastiği vakum basıncı değerine, süt debisinin etkisini belirlemektir. Ölçümler CON, BIO ve MULTI sağım sistemlerinin ayrı ayrı kurulu olduğu farklı sağımhanelerde gerçekleştirilmiştir. $4.8 l_{\mathrm{min}^{-1}}$ sağım debisinde, b fazı sırasındaki ortalama meme 
lastiği vakum basıncı değeri CON'da $35 \mathrm{kPa}$, BIO da $32.6 \mathrm{kPa}$ ve MULTI'de $31.1 \mathrm{kPa}$ olarak bulunmuştur. Bu değerler ISO 5707 (2007) de vurgulanan 32-42 kPa'lık arzu edilen basınç değerlerine uyum göstermektedir. d fazındaki meme lastigi vakum değerleri sistemler arasında farklılık göstermekte olup bu değerler CON'da 34.2 $\mathrm{kPa}, M U L T I$ 'de $12.3 \mathrm{kPa}$ ve BIO'da $14.8 \mathrm{kPa}$ olarak saptanmıştır. CON ile diğer iki sistem arasında ortaya çıkan bu büyük farkın sebebi, Multilactor'ün meme başı alt kısmına periyodik hava girişine izin veren "Biomilker" adı verilen sisteme sahip olmasıdır.

Anahtar sözcükler: Meme lastiği vakumu; Nabız; b ve d-fazı; Vakum düşüşü

두 Ankara Üniversitesi Ziraat Fakültesi

\section{Introduction}

An effective milking technique is necessary to obtain all of the milk from the animal in the shortest time without causing any detrimental effect on udder health. The most direct measure of the effect of milking system on cows is the vacuum in the claw (Reinemann et al 2007). According to National Mastitis Council guidelines (1996), accurate recordings of vacuum levels at various locations during milking provide the best means of demonstrating the adequacy of the vacuum applied and regulator function for a stable vacuum condition of any milking system.

Quarter individual milking is such a system that eliminates inter-quarter transfer and it contributes to the improvement of udder health and mostly used in automatic milking systems (AMS). On the other hand, Rasmussen et al (2003) and Wirtz et al (2002) detected an increase in bulk milk somatic cell count (SCC) when using AMS. This shows the necessity of having additional methods to improve the milk quality and udder health of herd. In order to make use of the advantages of quarter individual milking, a new milking system called Multilactor ${ }^{\circledR}$ was developed. This system uses quarter individual milking in conventional milking parlour and it includes periodic air admission under each teat when the liner is closed at the end of each pulsation cycle like the BioMilker system. It has also a sequential pulsation system (Ö̈z et al 2008).

The objective of this study was to determine the effect of milk flow on the average liner vacuum at the teat end during the b-and d-phases of pulsation in conventional milking system (CON), conventional milking system with biomilker (BIO) and quarter individual milking system (MultilactorMULTI) by using a wet-test method, as defined in ISO 6690 (2007).

\section{Materials and Methods}

Three different types of milking system, one with conventional cluster, one again a conventional system with cluster having biomilker and a quarter individual milking unit were tested in similar tandem milking parlours located on a German dairy farm cooperating with the Leibniz-Institute for Agricultural Engineering Potsdam-Bornim. All of the milking parlours have a low level milkline and are equipped with milk meters.

The conventional milking cluster (Classic Westfalia 300) manufactured by GEA (Bönen, Germany) has a claw volume of $300 \mathrm{ml}(\mathrm{CON})$ and was used as a reference cluster. Alternative pulsation at a rate of 60 cycles per minute and the ratio of 60:40 was applied. The system working vacuum level was $40 \mathrm{kPa}$. The BioMilker Cluster (BIO), also manufactured by GEA (Bönen, Germany), is a conventional milking cluster with silicon liners like $\mathrm{CON}$ and this system allows periodic air ingress under the teat. The system working vacuum level was $35 \mathrm{kPa}$. The other milking machine parameters were equal to those of CON. The MultiLactor ${ }^{\circledR}$ Siliconform $\mathrm{GmbH}$, Türkheim, Germany) (MULTI) is a quarter individual milking system that can be used in a conventional milking parlour. The length and the inside diameter of the long milk tubes are $2100 \mathrm{~mm}$ and $10 \mathrm{~mm}$, respectively. The pulsation rate and the ratios were adjusted to the same levels as in the conventional milking parlour. The system working vacuum level was set to $38 \mathrm{kPa}$. The system allows periodic air ingress under the teat as in the BioMilker system (Hoefelmayr et al 1979) and uses silicon liners. This system has a different concept in terms of pulsation, sequential pulsation. Pulsation starts in each liner individually with successive teat cups being $25 \%$ out of phase. 
Vacuum measurements were conducted by using a wet-test stand (Figure 1) with four ISO artificial teats (ISO 6690 2007) placed in complete cluster. Water at room temperature as recommended in ISO 6690-2007 was used to simulate the effects of milk flow as it ranges between $0-6 \mathrm{~L} \mathrm{~min}^{-1}(0,0.8,2,2.8,4,4.8,5.6,6 \mathrm{~L}$ $\min ^{-1}$ ). Each flowmeter has a scale and a valve that allows adjusting the flow rate with an accuracy of $\pm 2 \%$. Vacuum was measured using a Bovi Press measuring system (A \& R Trading GmbH Echem, Germany) at a sampling rate greater than $300 \mathrm{~Hz}$ with a measuring accuracy of \pm 0.1 $\mathrm{kPa}$. The vacuum was recorded for 12 pulsation cycles for each measurement at the ISO-teat end, in the pulsation chamber, in the claw and in the main vacuum line, simultaneously. Since the claw does not exist in MULTI the necessary measurements were made at the junction point of four individual long milk tubes. The sensors were connected with a 16-gauge injection needle (BD Nokor Admix Kanüle 16G) to the short pulse tube and the claw. From the data recorded, the mean vacuum in the bphase, the mean vacuum in the d-phase, and the proportional share of the phases of the pulsation cycle were calculated for each of twelve pulsation cycles.

The determination of pulsation phases was achieved using a customized SAS macro according to the equation given in ISO 5707 (2007).

Evaluation of vacuum reduction was made with parametric tests based on a linear model. The collected data of the MultiLactor ${ }^{\circledR}$ were compared with vacuum measurements in conventional systems. The data were analyzed with the statistic software SAS 9.2 TS Level 2M0. For the calculations of mean values the MEANS procedure was used, while the linear model was formulated with the MIXED procedure. Graphs were made with the statistic software JMP, Version 8.0. Covariance Model equation is as follows:

$$
\underline{y}_{i}=\alpha_{i} x_{1}+\beta x_{2}+\underline{e}_{i}
$$

where $y_{i}$, random variable vacuum reduction $[\mathrm{N}(\mu$; $\left.\sigma_{e}^{2}\right)$ ]; $\alpha_{i}$, (fixed) effect of $i$-th level of factor $x_{1}$ (milking system); $\beta$, (fixed) effect of covariate $\mathrm{x}_{2}$ (flow rate); $\underline{\mathrm{e}}_{i}$, independent residual $\left[\mathrm{N}\left(0 ; \sigma^{2} \mathrm{e}\right)\right]$.
The model was fitted without an intercept, assuming no vacuum reduction at a flow rate of $0 l$ $\min ^{-1}$, since previous modeling showed no significant difference from 0 for the intercept.

\section{Results and Discussion}

Figure 2 depicts the results of the wet-test for the three different milking systems at flow rates ranging between 0 and $6 l \mathrm{~min}^{-1}$. For all systems, the teat end vacuum decreased with increasing flow, but the mean vacuum reductions for MULTI were greater than the values for $\mathrm{CON}$ and $\mathrm{BIO}$.

Tables 1 to 3 show significant differences of mean vacuum reduction and significant differences between MULTI, CON and BIO for vacuum reduction in the $\mathrm{b}$ - and $\mathrm{d}$ phase $(P \leq 0.05$ for all values). Mean vacuum values show the averages of the b- and d-phase.

Thus, these systems have to be compared in terms of the differences in b- and d-phases. Figure 3 depicts the mean vacuum reduction at the teat end in b- and d-phases at different flow rates. As seen from the figure, the slope of the lines for the $b$ and $d$ -phase vacuum reductions in CON is similar while the slopes of the vacuum reduction line for the two phases are different for BIO and MULTI.

Low milk flow up to $2 l \mathrm{~min}^{-1}$ caused equal vacuum reduction in the $b$-phase in all three systems. At higher milk flow starting at $2.5 l \mathrm{~min}^{-1}$ MULTI has a noticeably higher vacuum reduction in this phase.

It was found that, at an average flow rate of $4.8 l$ $\min ^{-1}$, the average vacuum in the liner during the $\mathrm{b}$ phase was $35.0 \mathrm{kPa}$ in $\mathrm{CON}, 31.6 \mathrm{kPa}$ in $\mathrm{BIO}$ and $31.1 \mathrm{kPa}$ in the MULTI system. This means that the mean vacuum reduction is $3.4 \mathrm{kPa}$ in $\mathrm{BIO}, 5 \mathrm{kPa}$ in CON and $6.9 \mathrm{kPa}$ in MULTI.

The average liner vacuum during the d-phase differed between the systems. It was $34.2 \mathrm{kPa}$ for CON, $13.9 \mathrm{kPa}$ for BIO and $12.3 \mathrm{kPa}$ for MULTI. This means that the vacuum reduction is $25.7 \mathrm{kPa}$ in MULTI, $21.1 \mathrm{kPa}$ in BIO and in contrast $5.8 \mathrm{kPa}$ in CON. These values were obtained at an average flow rate of $4.8 l \mathrm{~min}^{-1}$. Generally a high reduction of teat end vacuum during the d-phase in MULTI was obtained. 


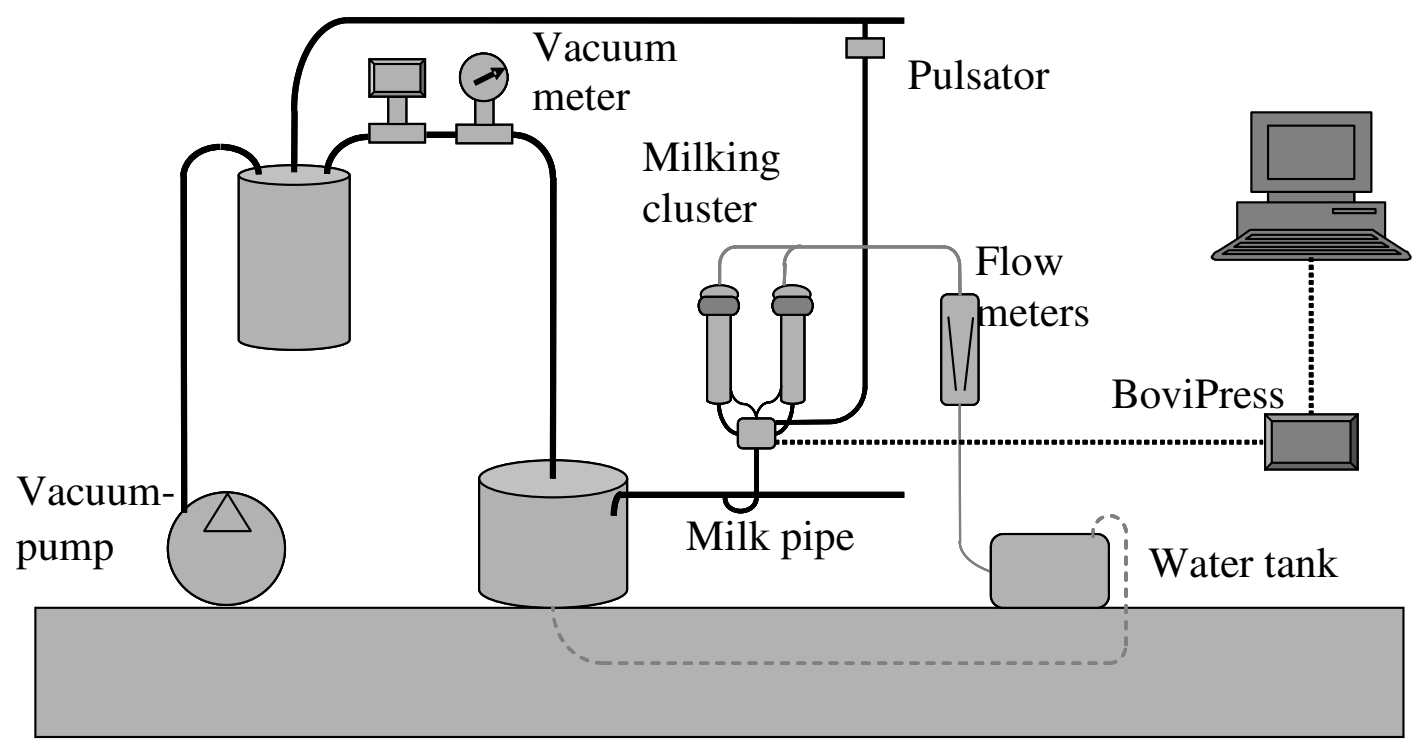

Figure 1-Schematic view of wet test stand

Şekil 1-Yaş deneme düzeninin şematik görünümü

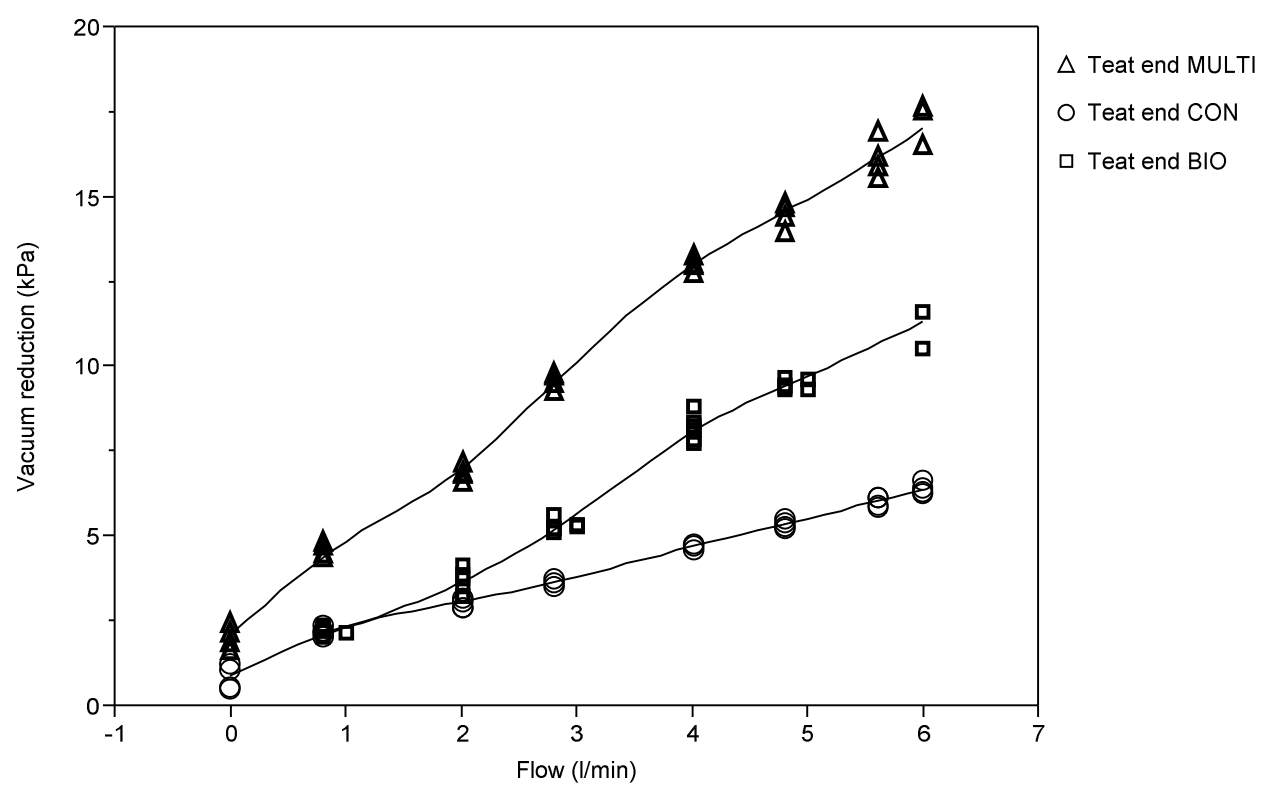

Figure 2-Vacuum reduction at the teat end in CON, BIO and MULTI at different flow rates Şekil 2-Farklı debilerde CON, BIO ve MULTI'de meme başı ucundaki vakum düşüşleri 


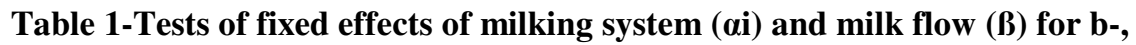
d-phase and mean vacuum at teat end

Çizelge 1-Să̆ım sisteminin ve debinin b ve d fazları ile memebaşı ucundaki ortalama vakum basıncı değerleri üzerine sabit etki testleri

\begin{tabular}{|c|c|c|c|c|c|}
\hline $\begin{array}{l}\text { Phase of pulse } \\
\text { cycle }\end{array}$ & effect & Num DF & $D E N D F$ & $F$-Value & $\operatorname{Pr}>|t|$ \\
\hline \multirow[t]{2}{*}{ b-phase } & $\alpha_{i}$ & 3 & 106 & 44 & $<.0001$ \\
\hline & B & 1 & 106 & 409 & $<.0001$ \\
\hline \multirow[t]{2}{*}{ d-phase } & $\alpha_{i}$ & 3 & 106 & 121 & $<.0001$ \\
\hline & $\beta$ & 1 & 106 & 256 & $<.0001$ \\
\hline \multirow[t]{2}{*}{ Mean vacuum } & $\alpha_{i}$ & 3 & 106 & 128 & $<.0001$ \\
\hline & $\beta$ & 1 & 106 & 463 & $<.0001$ \\
\hline
\end{tabular}

Table 2-Least square means of vacuum reduction at teat end for Multilactor (MULTI), BioMilker (BIO) and conventional milking system (CON)

Çizelge 2-Multilactor (MULTI), BioMilker (BIO) ve geleneksel sağım sistemlerinde (CON) meme başı ucundaki vakum düisüşlerinin en küçük kareler ortalaması

\begin{tabular}{lccccc}
\hline $\begin{array}{l}\text { Phase of pulse } \\
\text { cycle }\end{array}$ & Milking system & Estimate & Standard Error & $t$ Value & $\operatorname{Pr}>|t|$ \\
\hline b-phase & & & & \\
& MULTI & 5.2 & 0.18 & 29 & $<.0001$ \\
d-phase & CON & 4.1 & 0.16 & 25 & $<.0001$ \\
& BIO & 2.8 & 0.16 & 17 & $<.0001$ \\
& MULTI & 20.0 & 0.67 & 30 & $<.0001$ \\
Mean vacuum & CON & 4.3 & 0.59 & 7 & $<.0001$ \\
& BIO & 14.6 & 0.61 & 23 & $<.0001$ \\
& MULTI & 11.2 & 0.29 & 39 & $<.0001$ \\
& CON & 4.2 & 0.26 & 16 & $<.0001$ \\
\hline
\end{tabular}

Table 3-Differences of least square means of vacuum reduction at teat end for Multilactor (MULTI), BioMilker (BIO) and conventional milking system (CON)

Çizelge 3-Multilactor (MULTI), BioMilker (BIO) ve geleneksel sağım sistemlerinde (CON) meme başı ucundaki vakum düisüşlerinin en küçük kareler ortalamalarının farkı

\begin{tabular}{|c|c|c|c|c|c|}
\hline $\begin{array}{l}\text { Phase of pulse } \\
\text { cycle }\end{array}$ & Milking system & Estimate & Standard Error & $t$ Value & $\operatorname{Pr}>|t|$ \\
\hline \multirow[t]{2}{*}{ b-phase } & MULTI-CON & 1.11 & 0.24 & 4.58 & $<.0001$ \\
\hline & CON-BIO & -1.35 & 0.23 & -5.92 & $<.0001$ \\
\hline \multirow[t]{2}{*}{ d-phase } & MULTI-CON & 15.66 & 0.90 & 17.32 & $<.0001$ \\
\hline & MULTI-BIO & -5.36 & 0.91 & -5.89 & $<.0001$ \\
\hline \multirow{2}{*}{ Mean vacuum } & MULTI-BIO & -4.31 & 0.39 & -10.91 & $<.0001$ \\
\hline & CON-BIO & 2.67 & 0.37 & 7.20 & $<.0001$ \\
\hline
\end{tabular}




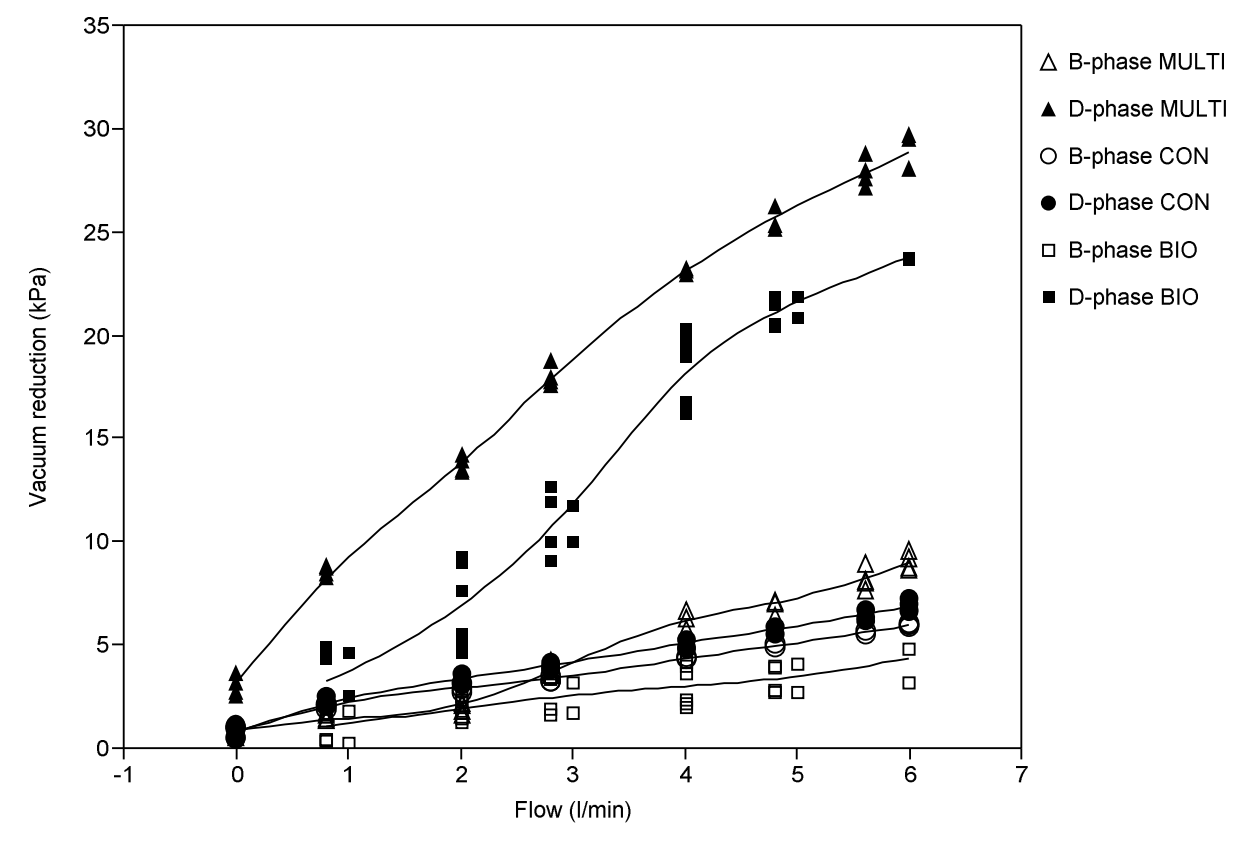

Figure 3-Vacuum reduction in b- and d-phase of CON, BIO and MULTI at different flow rates Şekil 3-Farklı debilerde CON, BIO ve MULTI'de b ve d fazlarında vakum düşüşleri

At a flow rate of $4.8 l \mathrm{~min}^{-1}$, the mean liner vacuum during the $b$-phase was calculated to be $35.0 \mathrm{kPa}$ in CON, $31.1 \mathrm{kPa}$ in MULTI and $32.6 \mathrm{kPa}$ in BIO. These vacuum levels are within the recommended range for cow milking and this was implied in ISO 5707 (2007) with a statement that "both research and field experience indicate that a mean liner vacuum within the range $32 \mathrm{kPa}$ to 42 $\mathrm{kPa}$ during the peak flow period of milking for cows ensures that most cows will be milked quickly, gently and completely". The mean liner vacuum during the d-phase, $4.8 l \mathrm{~min}^{-1}$ flow rate, were $34.2 \mathrm{kPa}$ for CON, $12.3 \mathrm{kPa}$ for MULTI and $14.8 \mathrm{kPa}$ for $\mathrm{BIO}$. The lower vacuum is to be expected since the MULTI and the BIO provide periodic air ingress under the teat. MULTI has a higher reduction than $\mathrm{BIO}$. The reason for this could be the long milk tubes with only $10 \mathrm{~mm}$ diameter. Worstorff et al (1983) asserted that periodical air ingress led to better liner collapse during the d-phase with a substantial improvement (reduction) in teat hardness, teat end lesions and cell count. Hamann et al (2001) showed that a positive pressure system resulted in a smaller teat end diameters and less teat thickness compared to a conventional system.

\section{Conclusion}

For CON, MULTI and BIO the teat end vacuum decreased with increasing flow. The vacuum in the b-phase for all three systems can be considered normal since the system working pressures were similar. The reduction of the mean vacuum level in the d-phase as the flow rate increases provides an effective massage on the teat. The appropriate vacuum level in b-phase and effective massage in d-phase provide a desired effect on teat and this combination could be considered as an advantage of the MULTI system.

\section{Acknowledgements}

The authors thank "Siliconform GmbH" for their kind help in providing the Multilactor ${ }^{\circledR}$. This study was funded by German Aerospace Center (DLR) as a Management Agency for the Federal Ministry of Education and Research (BMBF). 


\begin{tabular}{|ll|}
\hline Nomenclature & \\
\hline BIO & Biomilker, periodic air inlet under the teat \\
MULTI & Conventional milking system \\
$b$ phase & Multilactor, quarter individual milking system \\
$d$ phase & Message phase of pulsation cycle \\
$y_{i}$ & Random variable vacuum reduction, $\mathrm{N}\left(\mu ; \sigma_{\mathrm{e}}^{2}\right)$ \\
$\alpha_{i}$ & (fixed) effect of i-th level of factor $\mathrm{x}_{1}(\mathrm{milking}$ system) \\
$\beta$ & (fixed) effect of covariate $\mathrm{x}_{2}$ (flow rate) \\
$e_{i}$ & independent residual, $\mathrm{N}\left(0 ; \sigma_{\mathrm{e}}^{2}\right)$ \\
\hline
\end{tabular}

\section{References}

Hamann J, Bronzo V, Moroni P, Casula A \& Zecconi A (2001). Conventional and positive pressure pulsation effects on bovine teats and on immunological components of different milk fractions. Milchwissenshaft (Milk Science International) 56(8): 423-427

Hoefelmayr T \& Maier J (1979). So arbeitet der BioMilker. Milchpraxis 17: 2-65

ISO/DIN 5707 (2007). Milking machine installations constructions and performance. International Organization for Standardization, Geneva, Switzerland

ISO/DIN 6690 (2007). Milking machine installations mechanical tests. International Organization for Standardization, Geneva, Switzerland

NMC (1996). Procedures for Evaluating Vacuum Levels and Air Flow in Milking Systems. The National Mastitis Council, Madison, Wisconsin, USA

Oz H, Rose S, Brunsch R \& Bilgen H (2008). Wet and Dynamic Tests in Conventional and Single Tube Milking Clusters. In: Proceedings of the AgEng2008International Conference on Agricultural
Engineering-Agricultural \& Biosystems Engineering for a Sustainable World, 23-25 June, Paper No. OP 495, Hersonissos-Kreta, Greece

Rasmussen M.D, Reinemann D.J \& Mein G.A (2003). Measuring Vacuum in Milking Machines. International Dairy Federation. Bulletin-FIL-IDF (Belgium) 381, 19-32

Reinemann D.J, Schuring N \& Bade R.D (2007). Methods for measuring and interpreting milking vacuum. In: Proceedings of Sixth International Dairy Housing Conference. 16-18 June, Minneapolis, Minnesota, USA

Wirtz N, Oechtering K, Tholen E, Trappman W, McLean J (ed.) \& Sinclair M (ed.) (2002). Comparison of an automatic milking system to a conventional milking parlor. In Prooceedings of First North American Conference on Robotic Milking, III50-III-53, Toronto, Canada

Worstorff H, Prediger A \& Auernhammer H (1983). Effect of periodical air inlet cluster on teat condition, milk yield and udder health of cows. Milchwissenschaft (Milk Science International) 38: 528-530 